\title{
Renovascular Hypertension Due to Bilateral Renal Artery Stenosis: A Case Report of A 4-Month-Old Infant
}

\author{
Bilateral Renal Arter Darlığına Bağlı Renovasküler Hipertansiyon: 4 Aylık Bir \\ Bebeğin Olgu Sunumu
}

\author{
๑Vildan Güngörer ${ }^{1}$, @Resul Yılmaz ${ }^{2}$, ๑Ahmet Sert ${ }^{3}$, ๑Alaaddin Nayman ${ }^{4}$, @Şükrü Arslan ${ }^{1}$ \\ 'Selcuk University School of Medicine Department of Pediatrics, Division of Pediatric Rheumatology, Konya, Turkey \\ ${ }^{2}$ Selcuk University School of Medicine Department of Pediatrics, Division of Pediatric Critical Care, Konya, Turkey \\ ${ }^{3}$ Selcuk University School of Medicine Department of Pediatrics, Division of Pediatric Cardiology, Konya, Turkey \\ ${ }^{4}$ Selcuk University School of Medicine Department of Radiology, Konya, Turkey
}

\begin{abstract}
Renovascular hypertension is one of the most common causes of secondary hypertension. Renovascular hypertension causes $5-10 \%$ of childhood hypertension. Renal artery stenosis is the most important cause of renovascular hypertension. Patients with renovascular hypertension may be asymptomatic or present with many symptoms such as headache, vomiting, convulsion, heart disease, and sudden death. In renovascular hypertension, surgical treatment may be required in severe high blood pressure that does not respond to medical treatment. In this study, we present a four-month-old infant who developed renovascular hypertension due to bilateral renal artery stenosis, which was controlled by angiotensin II receptor blockers.
\end{abstract}

Keywords: Angiotensin II receptor blockers, renal artery stenosis, renovascular hypertension, treatment

\section{ÖZ}

Renovasküler hipertansiyon, sekonder hipertansiyonun en yaygın nedenlerinden biridir. Renovasküler hipertansiyon, çocukluk çağı hipertansiyonunun\% 5-10'una neden olur. Renal arter darlığı, renovasküler hipertansiyonun en önemli nedenidir. Renovasküler hipertansiyonu olan hastalar asemptomatik olabilir veya baş ağrısı, kusma, konvülsiyon, kalp hastalığı ve ani ölüm gibi birçok semptomla başvurabilirler. Renovasküler hipertansiyonda medikal tedaviye cevap vermeyen şiddetli yüksek tansiyonda cerrahi tedavi gerekebilir. Bu çalışmada anjiyotensin II reseptör blokerleri ile kontrol edilen bilateral renal arter stenozuna bağı renovasküler hipertansiyon gelişen dört aylık bir bebeği sunuyoruz.

Anahtar Kelimeler: Anjiyotensin II reseptör blokerleri, renal arter stenozu, renovasküler hipertansiyon, tedavi

\section{INTRODUCTION}

Renovascular hypertension is one of the most common causes of secondary hypertension (1). Renovascular hypertension causes 5\%-10\% of childhood hypertension, and renal artery stenosis is the most important cause of renovascular hypertension. The most common causes of renal artery stenosis are fibromuscular dysplasia (FMD), the middle aortic syndrome (MAS), Takayasu's arteritis in Asian countries, neurofibromatosis type 1 (NF1), Williams syndrome, tuberous sclerosis, and other vasculitis (2).

Patients with renovascular hypertension may be asymptomatic or may present with symptoms such as headache, vomiting, convulsion, heart disease, and sudden death $(3,4)$. Renal artery stenosis can be detected using various imagining modalities such as angiography, Doppler ultrasonography (USG), computed tomography angiography (CTA), and magnetic resonance angiography (MRA) (5).

In renovascular hypertension, surgical treatment may be required in severe high blood pressure that does not respond to medical treatment. So, far, however, the existing literature has reported a small number of cases who have bilateral lesions at a young age and need surgical intervention (6). In this study, we present a 4-month-old infant who developed renovascular hypertension due to bilateral renal artery stenosis, which was controlled by medical treatment. 


\section{CASE REPORT}

A male patient aged 4 months and 23 days was admitted to the pediatric emergency department with fever, vomiting, and sleepiness. Fever was 37,4 centigrade degrees and blood pressure was measured 100/50 $\mathrm{mmHg}$ at admission. His capillary refill time was long. Other physical examinations were normal. Complete blood count and renal function tests (blood urea 30 $\mathrm{mg} / \mathrm{dl}$, serum creatinine $0.52 \mathrm{mg} / \mathrm{dl}$ ) were within normal ranges. Hyponatremia $(130 \mathrm{mEq} / \mathrm{L})$, hypochloremia (94 mEq/l) were detected. Other biochemical analyzes and acute phase reactans were normal. Urinalysis indicated $\mathrm{Ph}$ of 6 , density:1035 and +3 proteins. There was no bacterial growth in the patient's urine culture. A lumbar puncture was performed, and he was hospitalized in the general pediatric department with a preliminary diagnosis of meningitis or sepsis. On admission rehydration and sodium chloride treatment were started. While hospitalized, the patient had good oral intake and no fever and vomiting; his discomfort was relieved. His cerebrospinal fluid (CSF) culture showed no abnormalities. He was given ceftriaxone therapy for 10 days, after which he was discharged. On the night of his discharge, the patient was admitted to the emergency department of an external center due to discomfort, refusal to breastfeed, vomiting, diarrhea, and sleepiness and was referred to our emergency department due to dehydration and hypovolemia. On admission to our emergency department, arterial blood pressure was $170 / 100 \mathrm{~mm} \mathrm{Hg}$, and his other vital signs were normal. In his physical examination, the patient was sleepy, there was no sign of dehydration, and no pathology was detected in the other system examinations. The parenteral fluid treatment initiated in the external center was discontinued, and the patient was given furosemide $1 \mathrm{mg} / \mathrm{kg}$ intravenous push and hospitalized in the intensive care unit. Three doses of nifedipine at $0.5 \mathrm{mg} / \mathrm{kg} /$ dose were initiated. The patient's blood pressure was around 120/80 mm Hg. The dose of furosemide was increased to $2 \mathrm{mg} / \mathrm{kg} /$ day. The results of biochemical analysis of blood samples were as follows: Na: $129 \mathrm{mEq} / \mathrm{L}, \mathrm{K}: 4.2 \mathrm{mmol} / \mathrm{L}, \mathrm{Cl}: 88.7$ mmol/L, Ca: 10.9 mg/dl, AST: $73 \mathrm{U} / \mathrm{L}, \mathrm{ALT}: 32 \mathrm{U} / \mathrm{L}$, urea: $25 \mathrm{mg} / \mathrm{dL}$, Cre: $0.3 \mathrm{mg} / \mathrm{dL}, \mathrm{Ck}: 55 \mathrm{U} / \mathrm{L}$, Alb: $4.26 \mathrm{~g} / \mathrm{dl}$, and CRP: $3.32 \mathrm{mg} / \mathrm{L}$. The other results were as follows: ACTH: $18.66 \mathrm{pg} / \mathrm{ml}$ cortisol: $31.49 \mathrm{ug} / \mathrm{dL}$, total testosterone $0.158 \mathrm{ug} / \mathrm{L}, \mathrm{DHEA}-\mathrm{SO} 4: 29.35 \mathrm{mg} / \mathrm{dL}, \mathrm{FSH}: 0.401 \mathrm{U} / \mathrm{L}$, LH: $3.56 \mathrm{U} / \mathrm{L}$, estradiol $<5 \mathrm{ng} / \mathrm{L}, \mathrm{Hb}$ in complete blood count (CBC): $15.6 \mathrm{~g} / \mathrm{dL}, \mathrm{WBC}: 9100 \mathrm{~K} / \mathrm{uL}, \mathrm{PLT}$ : 638,000 K/uL, neutrophils: $3000 \mathrm{~K} / \mathrm{uL}$, lymphocytes: $4800 \mathrm{~K} / \mathrm{uL}$, Ph in blood gas: $7.54-\log [\mathrm{H}], \mathrm{pCO} 2: 32 \mathrm{~mm} \mathrm{Hg}, \mathrm{pO} 2$ : $52 \mathrm{~mm} \mathrm{Hg}$, lactate: 2.4\%, sO2: 91\%, and HCO3: 27.8 $\mathrm{mmol} / \mathrm{L}$. The urinalysis results were as follows: $\mathrm{pH}$ : 6.5, density: 1025, $\mathrm{Hb}:++\mathrm{mg} / \mathrm{dL}$, leukocytes: $1 \mathrm{HPF}$, and normal urine electrolytes. Nifedipine therapy was added to furosemide on 2 days in a week and followed up. Echocardiography showed dilated cardiomyopathy (DCM), first-degree mitral regurgitation (MR), and a secundum atrial septal defect. The results of renal USG and renal Doppler USG were considered normal. There was no hypertensive retinopathy in fundus examination. Aldosterone and renin tests were performed. Enalapril (at $0.5 \mathrm{mg} / \mathrm{kg}$ dose) was added to his therapy when his blood pressure tended to increase again. In renovascular hypertension, enalapril therapy results in dilatation of the efferent arteriole, thereby leading to reduced glomerular blood flow, reduced glomerular filtration, and deteriorating renal function. Therefore, we thought that enalapril would lead to a diagnosis of renovascular hypertension. Magnetic resonance angiography (MRA) was performed. Decreased urine output was observed, and creatinine increased to 1.82 $\mathrm{mg} / \mathrm{dL}$ during follow-up. This result was consistent with renovascular hypertension. Enalapril therapy was discontinued. The level of creatinine decreased to $0.44 \mathrm{mg} / \mathrm{dL}$ within 2 days of follow-up. However, the MRA results were interpreted as normal. Because the blood tests results showed renin $>500 \mathrm{pg} / \mathrm{mL}$ and aldosterone $5075 \mathrm{pg} / \mathrm{mL}$, the diagnosis of renovascular hypertension was confirmed. Because computed tomography angiography is more reliable in the diagnosis of renovascular diseases, CTA was performed and was interpreted as follows: "stenotic segments were observed which impeded the inflow of the contrast medium in an approximately $1-\mathrm{cm}$ segment from the origin of both renal arteries from the abdominal aorta" (Figure 1). The patient's blood pressure increased again. Because alpha blockers and beta blockers might be risky due to DCM, angiotensin II receptor blockers (ARBs) were initiated. No hypertension or renal function disorder were observed during follow-up. Nifedipine and ARBs therapy was continued. Interventional radiology was consulted for dilatation of the stenosis. No intervention was considered until the age of 1 , by the joint decision of the cardiovascular surgery and interventional radiology departments because the patient was only 4 months old, the rate of complications might be high, and his blood pressure was currently controlled by antihypertensive medications. The patient, who was asymptomatic, had stable blood pressure and normal laboratory values, was discharged with Nifedipine and ARBs therapy.

\section{DISCUSSION}

Renovascular hypertension is defined as elevated blood pressure caused by occlusion of one or both of the main renal arteries or its branches. Renovascular hypertension generally caused by renal artery stenosis is one of the most common forms of detectable secondary hypertension (7). The most common cause of renal 


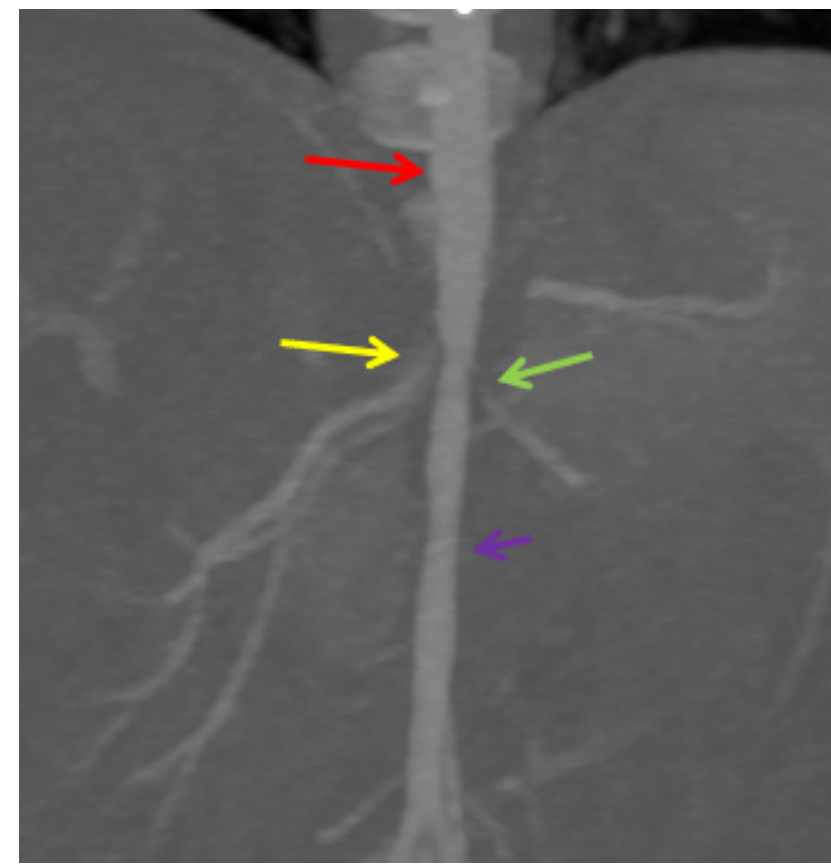

Figure 1. Computed tomography angiography MIP (maximum intensity projection) of abdominal aorta

Red arrow: Suprarenal normal aorta

Purple arrow: Infrarenal hypoplasic aorta

Yellow (Right) and Green (Left) arrows: Preocclusion images of renal artery origin

artery stenosis is FMD, but it can also be secondary to renal tumor compression or to mechanical compression due to massive hydronephrosis. Other causes include MAS, perirenal hematomas, idiopathic arterial calcification, renal myofibromatosis, Takayasu's arteritis, neurofibromatosis type 1 (NF1), Williams syndrome, tuberous sclerosis, and other vasculitis (8). FMD accounts for $60 \%$ of all renovascular hypertension cases (9). FMD is an idiopathic, non-inflammatory arteriopathy associated with the proliferation of medial smooth muscle cells and fibrous tissue, which may cause arterial stenosis, occlusion, aneurysm, and dissection. FMD is the most common cause of hypertension in pediatric patients. The disease involves renal arteries in most cases (70\%), while carotid arteries are frequently (65\%) affected (10). There is no difference between the genders in childhood; renal artery stenosis is bilateral in approximately $50 \%$ of cases. In FMD, all arterial beds (vertebral, subclavian, iliac, and visceral arteries) may be affected (10).

MAS is characterized by segmental or long segmental narrowing of the abdominal or distal descending thoracic aorta. It comprises $2 \%$ of all aortic coarctations. In this type of coarctation, proximal renal artery stenosis is seen in $80 \%$ of cases (11). Renal artery atresia may be accompanied by hypoplasia, dysplasia, and congenital MAS (12).

While acute-phase reactants of patients are high in Takayasu's arteritis and other vasculitis, other clinical findings are also observed. In the light of clinical, laboratory, and imaging findings, we thought that our patient might have FMD and MAS because the current physical examination and laboratory findings were not consistent with other diseases. However, we were unable to perform a histopathological examination for the differential diagnosis of FMD due to his young age and low weight.

Children with renovascular hypertension may be clinically asymptomatic or present with clinical scenarios such as headache, nausea, vomiting, convulsion, heart failure, and death $(3,4)$. One of the most feared scenarios is aneurysm rupture (10). Our patient presented with nausea, vomiting, and an altered state of consciousness on the first admission. The preliminary diagnosis was viral meningitis, and hypertension was out of focus.

The pathophysiology of renovascular hypertension varies depending on whether renal artery stenosis is unilateral or bilateral. In case of unilateral renal artery stenosis, it leads to reduced renal perfusion in the stenotic kidney and increased synthesis of renin and angiotensin II due to the decreased sodium and chlorine concentration in the macula densa, thereby causing the blood pressure to increase. Sodium and water reabsorption decreases due to normal perfusion in the other kidney; thus, patients are normovolemic. In cases with a single kidney or bilateral renal artery stenosis, renal perfusion decreases in the stenotic kidney, and sodium and water reabsorption increases; thus, patients develop hypervolemia due to the dysfunctional mechanism of compensatory excretion (13).

Our patient had bilateral renal artery stenosis. We initiated angiotensin-converting enzyme (ACEls) inhibitors, which led to dilatation of the efferent arteriole. His renal function was impaired due to reduced glomerular filtration caused by decreased glomerular blood flow. This situation served as a diagnostic guide as we focused on a preliminary diagnosis of renovascular hypertension. ACEls are contraindicated in patients with renovascular hypertension due to the mechanism described above. We did not administer alpha blockers and beta blockers for the treatment of hypertension because our patient had DCM. We administered ARBs. In fact, ARBs may block the aldosterone- and vasopressin-producing activity of angiotensin II through the AT1 receptor and by extension, the vasoconstriction effect of angiotensin II, thereby leading to dilatation of the efferent arteriole. Angiotensin II has four types of receptors; however, it mediates effects through two main receptors. The functions of AT3 and AT4 receptors are unknown. AT2 receptors balance the effects mediated by the AT1 (14). Therefore, we thought that ARBs might not affect renal function because we did not know the receptor distribution in the efferent arteriole. Indeed, ARBs did not cause deterioration of the patient's renal function during follow-up. Accordingly, we can consider the use of ARBs in renovascular hypertension as an alternative treatment option to ACE inhibitors. 
Digital subtraction angiography (DSA) is the most reliable method and the gold standard in the diagnosis of renal vascular diseases, allowing the main renal arteries and all distal branches to be visualized. However, patients should be selected carefully for DSA because it is an invasive method and often requires general anesthesia. To select patients for DSA, less invasive examinations should be performed and according the results referred to DSA (15). At present, $\mathrm{CT}$ angiography is widely used in the diagnosis of renovascular artery stenosis. In our case, stenosis was detected not by Doppler USG and MR angiography but by $C T$ angiography. In fact, MR angiography is also used widely and successfully to detect stenosis in the main renal arteries because it does not use radiation. However, we didn't detect stenosis by using MRA because our patient was too young and MRA is sensitive to motion.

The treatment of renovascular hypertension is based on amelioration of the effects of hyperreninemia. The aim of treatment is to control blood pressure and to prevent and reverse problems caused by ischemia due to renal artery stenosis. The severity of hypertension, the etiology of renovascular hypertension, the extent of renal function impairment and the presence of comorbidities that affect patient survival are of key importance in treatment selection (13).

There are four treatment options for renovascular hypertension:

1) medical treatment, 2) percutaneous renal transluminal angioplasty with/without stent implantation 3) surgical treatment.

In consultation with the departments of interventional radiology, cardiovascular surgery, and pediatric nephrology, we jointly decided to perform invasive histopathological examination and treatment under elective conditions after the patient reaches 1 year of age as long as his hypertension can be controlled with medication, because our patient weighed less than $5 \mathrm{~kg}$. Our patient's blood pressure was controlled with two antihypertensives.

To conclude, although renovascular hypertension occurs relatively more frequently in adolescents, it can also be seen in infants and children. The underlying pathological condition is usually FMD and renal artery stenosis. Therefore, blood pressure measurement is vitally important, especially for patients who present with clouding of consciousness, general condition disorder, and vomiting, regardless of age, to avoid overlooking hypertension and to prevent associated end-organ damage.

\section{ETHICAL DECLARATIONS}

Informed Consent: Written informed consent was obtained from all participants who participated in this study.
Referee Evaluation Process: Externally peer-reviewed. Conflict of Interest Statement: The authors have no conflicts of interest to declare.

Financial Disclosure: The authors declared that this study has received no financial support.

Author Contributions: All of the authors declare that they have all participated in the design, execution, and analysis of the paper, and that they have approved the final version.

\section{REFERENCES}

1. Rumman RK, Nickel C, Matsuda-Abedini M, et al. Disease beyond the arch: a systematic review of middle aortic syndrome in childhood. Am J Hypertens 2015; 28: 833-46.

2. Tullus K, Brennan E, Hamilton G, et al. Renovascular hypertension in children. Lancet 2008; 371: 1453-63.

3. Herrmann SM, Textor SC. Renovascular hypertension. Endocrinol Metabol Clin 2019; 48(4), 765-78.

4. Mehta AN, Fenves A. Current opinions in renovascular hypertension. In: Baylor University Medical Center Proceedings. Taylor Francis 2010. p. 246-9.

5. Arslan C, Bitargil M, Arapi B, Tel Ç, Tüzün KH. Renal Artery Stenosis and Aneurysm in a Child: Case Report. Damar Cerrahi Derg 2014; 23: 186-9.

6. Mir S, Kara PE, Dönmez O, Hoşcoşkun C, Kabasakal C. Renovascular Hypertension Due to Bilateral Renal Artery Stenosis and Surgical Treatment: A Case Report of a 14 Month-Old Infant. Turkiye Klinikleri Journal of Pediatrics. 2005; 14: 150.

7. Yıldız S, Yaylalı YT. Renovasküler Hipertansiyon. Turkiye Klinikleri Cardiovascular Sciences. 2012; 24: 206-12.

8. Marks SD, Tullus K. Update on imaging for suspected renovascular hypertension in children and adolescents. Curr Hypertens Rep 2012; 14: 591-5.

9. Estepa NG, L. Orte, E. Puras, E. Aracil, J. Ortuño, R. Renovascular hypertension in children. Scand J Urol Nephrol 2001; 35: 388-92.

10. Olin JW, Pierce M. Contemporary management of fibromuscular dysplasia. Curr Opin Cardiol 2008; 23: 527-36.

11. Saif I, Seriki D, Moore R, Woywodt A. Midaortic syndrome in neurofibromatosis type 1 resulting in bilateral renal artery stenosis. Am J Kidney Dis 2010; 56: 1197-201.

12. Delis KT, Gloviczki P. Middle aortic syndrome: from presentation to contemporary open surgical and endovascular treatment. Perspect Vasc Surg Endovasc Ther 2005;17(3):187-203.

13. Gottam N, Nanjundappa A, Dieter RS. Renal artery stenosis: pathophysiology and treatment. Expert Rev Cardiovasc Ther 2009; 7: 1413-20.

14. Inagami T, Senbonmatsu T. Dual effects of angiotensin II type 2 receptor on cardiovascular hypertrophy. Trends Cardiovasc Med 2001;11:324-8.

15. Flynn JT, Ingelfinger JR, Portman RJ. Pediatric hypertension.3 th ed.New York: Springer, 2013, p.600 . 